\title{
Influence of Carbon Source on Biological Nitrogen Removal by Immobilised Bacteria
}

\author{
Wilawan Khanitchaidecha ${ }^{1}$, Tatsuo Sumino ${ }^{2}$, Futaba Kazama ${ }^{1}$ \\ ${ }^{1}$ Interdisciplinary Graduate School of Medicine and Engineering, University of Yamanashi, Yamanashi, Japan \\ ${ }^{2}$ Matsudo Research Laboratory, Hitachi Plant Technologies, Chiba, Japan \\ E-mail:wilawank1@gmail.com,kfutaba@yamanashi.ac.jp,tatsuo.sumino.cj@hitachi-pt.com \\ Received January 8, 2010; revised March 24, 2010; accepted April 20, 2010
}

\begin{abstract}
Acetate, ethanol, and hydrolysed rice were used as external carbon sources in an ammonium removal process employing immobilised bacteria. The influence of the carbon source on the occurrence of free cells and total nitrogen removal efficiency was examined at $\mathrm{C} / \mathrm{N}$ ratios of 1.5 (low), 2.5 (medium), and 3.5 (high). At the low $\mathrm{C} / \mathrm{N}$ ratio, no free cells were found in the reactors and the use of acetate as the carbon source resulted in the highest total nitrogen removal efficiency, followed by ethanol and hydrolysed rice. The occurrence of free cells in reactors fed with acetate and ethanol led to a negligible increase in the total nitrogen removal efficiency with increasing $\mathrm{C} / \mathrm{N}$ ratio. The results suggest that acetate is the most appropriate carbon source for nitrogen removal and that the number of free cells should be minimized to achieve the highest efficiency during long-term operation.
\end{abstract}

Keywords: Nitrogen Removal, Nitrification and Denitrification, Carbon Sources

\section{Introduction}

During the past few decades, biological ammoniumnitrogen $\left(\mathrm{NH}_{4}-\mathrm{N}\right)$ removal has emerged as one of the most interesting methods for water and wastewater treatment. The system consists of a nitrification process $\left(\mathrm{NH}_{4}-\mathrm{N} \rightarrow \mathrm{NO}_{3}-\mathrm{N}\right.$ (nitrate-nitrogen)) followed by denitrification to produce non-toxic nitrogen gas $\left(\mathrm{NO}_{3}-\mathrm{N} \rightarrow\right.$ $\mathrm{N}_{2}$ ). In general, nitrification is an aerobic process and denitrification is an anaerobic process. A source of organic carbon is an important component of the denitrification process. Several sources of carbon have been used including acetate [1-3], methanol [2,4], ethanol [1,3], glucose [3], peptone [3], glycerol [5], and lactic acid [5]. Additionally, solid waste-derived carbon sources such as molasses [6], corncobs [7], and excess sludge [8] have also been used. Table 1 provides a comparison of the nitrogen removal efficiency obtained using various carbon sources. Of these, acetate and ethanol are attractive and versatile substrates due to biodegradability, low consumption (mg-C/mg-N), and low toxicity. Despite the effort invested in exploring biological nitrogen removal, there are few reports on the influence of the carbon source on $\mathrm{N}$ removal efficiency, particularly acetate vs. ethanol $[9,10]$, and no research on the occurrence of free cells when using various carbon sources. Free cells are commonly found in immobilised sludge systems, and result in ineffective $\mathrm{NH}_{4}-\mathrm{N}$ removal. The present work examines the influence of external carbon sources including acetate, ethanol, and hydrolysed rice (representing a solid waste source) on nitrogen removal. The use of hydrolysed rice in $\mathrm{NH}_{4}-\mathrm{N}$ removal provides a potential means of waste reduction.

\section{Materials and Methods}

\subsection{Solution Preparation}

Simulated wastewater influent solution containing $40 \mathrm{mg} / \mathrm{L}$ of $\mathrm{NH}_{4}-\mathrm{N}$ was prepared by mixing $0.19 \mathrm{~g} / \mathrm{L}$ of $\left(\mathrm{NH}_{4}\right)_{2} \mathrm{SO}_{4}$, $0.48 \mathrm{~g} / \mathrm{L}$ of $\mathrm{NaHCO}_{3}, 0.05 \mathrm{~g} / \mathrm{L}$ of $\mathrm{KCl}, 0.11 \mathrm{~g} / \mathrm{L}$ of $\mathrm{CaCl}_{2} \cdot 2 \mathrm{H}_{2} \mathrm{O}, 0.1 \mathrm{~g} / \mathrm{L}$ of $\mathrm{MgSO}_{4} \cdot 7 \mathrm{H}_{2} \mathrm{O}$, and $0.02 \mathrm{~g} / \mathrm{L}$ of $\mathrm{Na}_{2} \mathrm{HPO}_{4} \cdot 12 \mathrm{H}_{2} \mathrm{O}$. The carbon concentration of acetate and ethanol feed solutions was fixed at $7.1 \mathrm{~g} / \mathrm{L}$.

Hydrolysed rice was prepared by adding $35 \mathrm{~g}$ of rice and $18 \mathrm{~mL}$ of $6 \mathrm{M} \mathrm{HCl}$ to $1 \mathrm{~L}$ of tap water. The solution was heated to $90^{\circ} \mathrm{C}$ for 24 hours. The resulting carbon concentration of the hydrolysed rice solution was 6.5-7.0 $\mathrm{g} / \mathrm{L}$ of total organic carbon (TOC) and $\sim 0.1 \mathrm{~g} / \mathrm{L}$ of volatile organic carbon (VOC). 
Table 1. Nitrogen removal efficiency and $\mathrm{C} / \mathrm{N}$ ratio requirement observed using various carbon sources.

\begin{tabular}{lccc}
\hline $\begin{array}{c}\text { Carbon } \\
\text { source }\end{array}$ & $\begin{array}{c}\text { C/N ratio } \\
(\mathrm{mg}-\mathrm{C} / \mathrm{mg}-\mathrm{N})\end{array}$ & $\begin{array}{c}\text { Nitrogen } \\
\text { removal } \\
\text { efficiency } \\
(\%)\end{array}$ & Reference \\
\hline Acetate & 1.5 & $90-100$ & {$[2]$} \\
Methanol & 1.5 & $90-100$ & \\
Acetate & 5.0 & $\sim 100$ & {$[3]$} \\
Glucose & 5.0 & $\sim 100$ & \\
Acetic acid & 1.1 & $\sim 100$ & {$[9]$} \\
Ethanol & 0.6 & $\sim 100$ & \\
Acetic acid & 4.3 & 98 & {$[10]$} \\
Ethanol & 2.35 & 91 & \\
Methanol & 2.9 & 93 & {$[11]$} \\
Ethanol & 2.5 & $\sim 100$ & {$[6]$} \\
Succinate & 2.5 & 92 & {$[7]$} \\
Molasses & $6^{\mathrm{a}}$ & 90 & \\
Corncobs & $1.5^{\mathrm{a}}$ & & \\
${ }^{\mathrm{a}}$ mg-COD/mg-N ratio & & & \\
\end{tabular}

\subsection{Polyethylene Glycol (PEG) Pellet Preparation}

Sludge was collected from the first sedimentation tank of a drinking water plant in Kofu, Japan. A $34.5 \mathrm{~mL}$ portion of $10 \%$ concentrated sludge was mixed with $10.5 \mathrm{~mL}$ of a solution containing PEG pre-polymer and promoter, and $5 \mathrm{~mL}$ of potassium persulfate $\left(\mathrm{K}_{2} \mathrm{~S}_{2} \mathrm{O}_{8}\right)$ was added to initiate polymerization. The polymerized gel was cut into $3 \mathrm{~mm}$ cubes referred to as PEG pellets.

\subsection{Reactor Set-up}

A 3L acrylic reactor $(12.5 \times 16 \times 20 \mathrm{~cm})$ was separated into two identical chambers (the aeration and non-aeration chambers) by an acrylic plate perforated by a number of small holes (Figure 1). The aeration chamber contained $8 \mathrm{~g}$ of support material (polyester textile, Networking of Engineering and Textile Processing (NET) Company, Japan) and $0.05 \mathrm{~L}$ of $10 \%$ concentrated sludge. The bulk dissolved oxygen (DO) concentration was maintained at 5-6 mg/L, and the $\mathrm{NH}_{4}-\mathrm{N}$ solution (influent) was continuously supplied at a rate of $0.2 \mathrm{~L} / \mathrm{h}$. The non-aeration chamber contained $0.6 \mathrm{~L}$ of PEG pellets, and the bulk DO concentration ranged from $4-5 \mathrm{mg} / \mathrm{L}$. In order to investigate the effect of carbon source at various $\mathrm{C} / \mathrm{N}$ ratios, the carbon source solution was fed to the non-aeration chamber for 10 min every 4 hours at a rate of $\sim 42 \mathrm{~mL} / \mathrm{h}$ (for the $1.5 \mathrm{C} / \mathrm{N}$ ratio), $\sim 70 \mathrm{~mL} / \mathrm{h}$ (for the $2.5 \mathrm{C} / \mathrm{N}$ ratio), or $\sim 98 \mathrm{~mL} / \mathrm{h}$ (for the $3.5 \mathrm{C} / \mathrm{N}$ ratio). The hydraulic retention time of the reactors was approximately 12 hours.

\subsection{Analytical Methods}

The influent and effluent were analysed for $\mathrm{NH}_{4}-\mathrm{N}$, $\mathrm{NO}_{2}-\mathrm{N}$, and $\mathrm{NO}_{3}-\mathrm{N}$ concentrations using standard methods [12]. The total suspended solids (TSS) and VOC

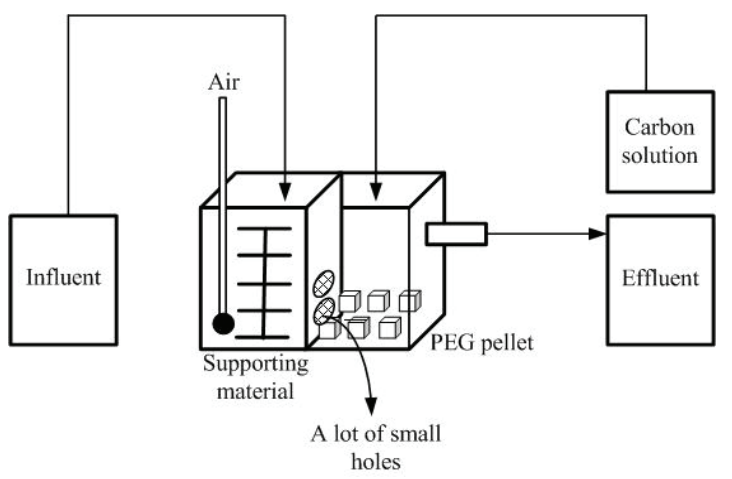

Figure 1. Schematic diagram of reactor design and operation.

contents were measured at irregular intervals in accordance with standard methods [12]. The organic carbon concentration was analysed using an organic carbon analyser (Shimadzu TOC-5050A). The temperature, $\mathrm{pH}$, and DO concentration of the reactor were measured onsite.

\section{Results and Discussion}

In the aeration chamber of all reactors, the complete liquid recirculation produced by continuous aeration resulted in attachment of the sludge bacteria to the supporting material. The conditions in this chamber included a high DO concentration and continuous influent $\mathrm{NH}_{4}-\mathrm{N}$ feed, resulting in nitrification being the main process in this chamber. Cultivation of nitrifying bacteria was indicated by a change in colour of the attached bacteria from dark to light brown. Nitrification was not the rate-limiting step in the process, since the zero concentration of $\mathrm{NH}_{4}-\mathrm{N}$ in the effluent indicated complete nitrification (Figures 2(a-d)).

The non-aeration chamber directly communicated with the aeration chamber through the perforated divider, and the water containing high concentrations of $\mathrm{NO}_{3}-\mathrm{N}$ and DO was immediately introduced to the non-aeration chamber. The DO concentration in the non-aeration chamber was $4-5 \mathrm{mg} / \mathrm{L}$. Although this concentration is somewhat higher than usual for denitrification, the limited oxygen diffusion into the pellet and oxygen consumption by bacteria near the pellet surface led to formation of an anaerobic zone in the pellet core where denitrification could occur. The $\mathrm{NO}_{3}-\mathrm{N}$ and added carbon (i.e. acetate, ethanol) diffused into the core as explained by Jun et al. [13]. The denitrifying bacteria were concentrated in the pellet core, while the region near the surface predominantly contained competing aerobic heterotrophic bacteria. In the present work, the denitrification process was the rate-limiting step of $\mathrm{NH}_{4}-\mathrm{N}$ removal and the efficiency of the denitrification process depended on the growth rate of competitive bacteria, the carbon consumption, and the carbon source. The effect of carbon 

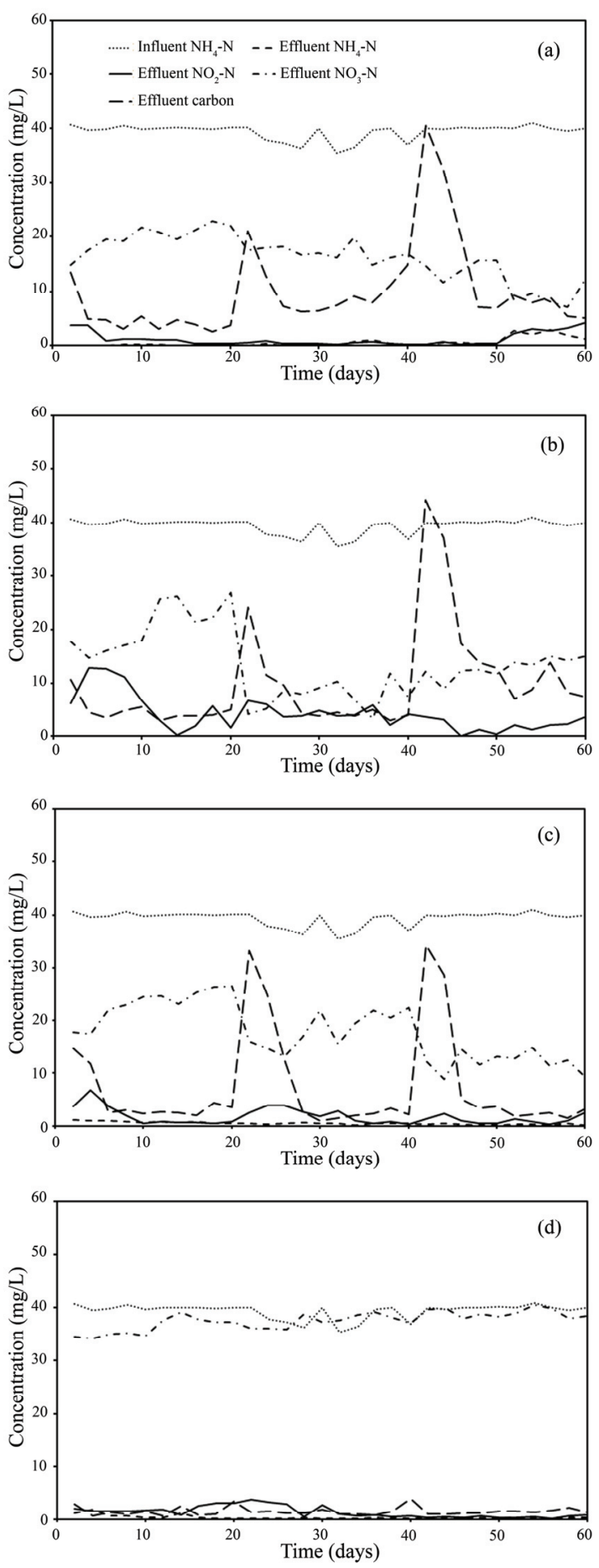

Figure 2. Nitrogen time course for (a) acetate-fed reactor; (b) ethanol-fed reactor; (c) hydrolysed rice-fed reactor, and (d) zero carbon feed reactor.

source on denitrification and growth of competing bacteria was examined during long-term operation (60 days).

Figure 3 depicts the total $\mathrm{N}\left(\mathrm{NH}_{4}-\mathrm{N}+\mathrm{NO}_{2}-\mathrm{N}+\mathrm{NO}_{3}-\mathrm{N}\right)$ removal efficiency for reactors fed with various carbon sources. It is not helpful to compare the efficiency be-

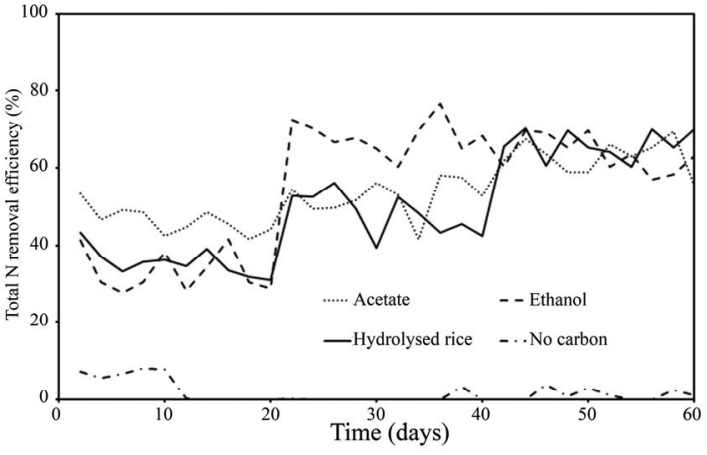

Figure 3. Total nitrogen removal efficiency of acetate-fed reactor, ethanol-fed reactor, and hydrolysed rice-fed reactor at $\mathrm{C} / \mathrm{N}$ ratios of $1.5,2.5$, and 3.5 , and zero carbon feed reactor.

-tween different $\mathrm{C} / \mathrm{N}$ ratios, because the reactors were continuously operated with step-wise increases in $\mathrm{C} / \mathrm{N}$ ratio. However, the effects of $\mathrm{C} / \mathrm{N}$ ratio and carbon source on the growth of competitive bacteria were evident, and the increase in competitive bacteria might eventually affect the $\mathrm{NH}_{4}-\mathrm{N}$ removal efficiency.

\subsection{Low C/N Ratio}

The $\mathrm{NH}_{4}-\mathrm{N}$ removal efficiency of reactors operated under different carbon feed conditions is illustrated in Figure 3, and the results are summarised in Table 2. The efficiency of the acetate-fed reactor was $46.5 \%$, higher than the ethanol-fed reactor at $33.1 \%$ or the hydrolysed rice-fed reactor at $35.5 \%$. Acetate is a readily biodegradable carbon source and is directly incorporated into the Krebs cycle to release energy for bacterial metabolism, while ethanol and hydrolysed rice require preliminary processing to convert them to acetic acid or pyruvic acid [14]. The utilization of acetate, ethanol, and hydrolysed rice for energy production in heterotrophic bacteria (i.e. denitrifying bacteria) is sketched in Figure 4. Constantin and Fick [9] reported that approximately $25 \%$ of the added carbon is expended during this preliminary conversion process, resulting in a decrease in the net carbon feed for the ethanol and hydrolyzed rice-fed reactors. The required energy (expressed as the Gibbs free

Table 2. Summary of average total nitrogen removal efficiency from Figure 3.

\begin{tabular}{lccc}
\hline \multirow{2}{*}{ Carbon Source } & \multicolumn{3}{c}{ Total N removal efficiency $(\%)$} \\
\cline { 2 - 4 } & $\begin{array}{c}C / N \text { ratio of } \\
1.5\end{array}$ & $\begin{array}{c}C / N \text { ratio of } \\
2.5\end{array}$ & $\begin{array}{c}C / N \text { ratio of } \\
3.5\end{array}$ \\
\hline Acetate & $46.5 \pm 3.5$ & $52.4 \pm 4.8$ & $63.1 \pm 4.4$ \\
Ethanol & $33.1 \pm 5.4$ & $68.3 \pm 4.8$ & $63.6 \pm 4.8$ \\
Hydrolysed rice & $35.5 \pm 3.7$ & $48.2 \pm 5.5$ & $66.2 \pm 3.9$ \\
No carbon & & $1.7 \pm 2.5$ & \\
\hline
\end{tabular}




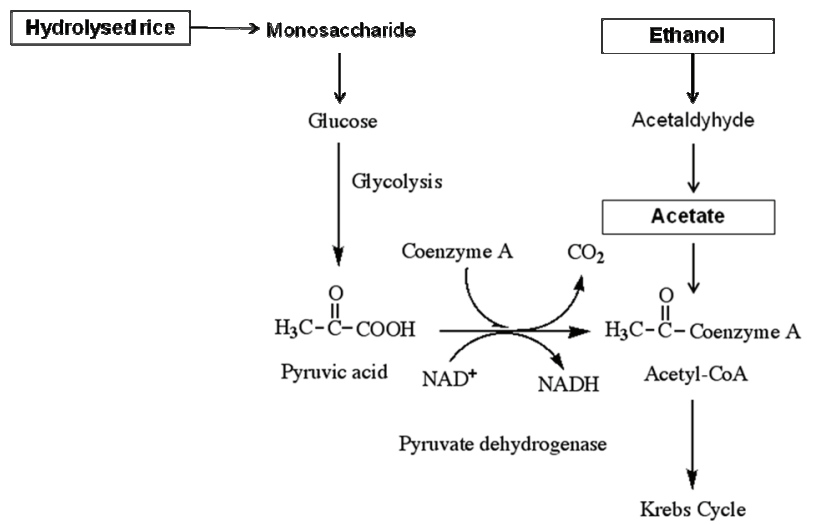

Figure 4. Process for carbon utilization by heterotrophic bacteria (modified from Akunna et al. [14]).

energy $\Delta \mathrm{G}$ ) for bacterial metabolism via acetate, ethanol, and glucose (the monomer of rice starch) consumption are $1110.5,1325$, and $2825 \mathrm{~kJ} / \mathrm{mol}$ [15]. The consumption of acetate requires the least energy, supporting the preceding explanation that acetate is more easily utilized by heterotrophic bacteria.

The similar efficiency when using ethanol and hydrolysed rice as carbon sources reflects the incomplete hydrolysis (low $\frac{\mathrm{VOC}}{\mathrm{DOC}}$ ) of the rice used as the carbon source, and the effective use of hydrolysed rice for $\mathrm{NH}_{4}-\mathrm{N}$ removal will require further study. In the reactor operated without a carbon source, the $\mathrm{N}$ removal efficiency was approximately $10 \%$ for 10 days, and eventually decreased to zero. Some nitrogen was removed during startup as stored carbon (i.e. Poly- $\beta$-hydroxybutyrate, PHB) was consumed as an energy source for denitrification [16]. The denitrification process ceased when the stored carbon was exhausted after 10 days of operation.

\subsection{Medium C/N Ratio}

At a $\mathrm{C} / \mathrm{N}$ ratio of 2.5 , the total $\mathrm{N}$ removal efficiency was highest in the ethanol-fed reactor, followed by the acetate and hydrolysed rice-fed reactors (Table 2). Suspended free cells were found in the non-aeration chamber of the acetate-fed reactor, but not in the other reactors. The occurrence of free cells in the acetate-fed reactor is due to a rapid increase in the number of competitive bacteria with increasing acetate concentration, followed by release from the pellet surface to the bulk solution. As discussed earlier, acetate is the most efficient carbon source for heterotrophic bacteria including denitrifying and other competitive bacteria. The free cells were pre- sent in the acetate-fed reactor at a concentration of $\sim 800$ $\mathrm{mg} / \mathrm{L}$ after 40 days.

In the acetate-fed reactor, some added carbon was consumed by the free cells, leaving less carbon available for denitrifying bacteria. Therefore, the total $\mathrm{N}$ removal efficiency was slightly decreased compared to the lower $\mathrm{C} / \mathrm{N}$ ratio, in contrast to the increased efficiency of the other two reactors. Further, the carbon concentration of $5-10 \mathrm{mg} / \mathrm{L}$ remaining in the effluent was higher than under low $\mathrm{C} / \mathrm{N}$ ratio operation (Figure 2(a)). This might be an effect of free cells on the activity of the denitrifying bacteria and their carbon consumption. The free cells in the non-aeration chamber of acetate-fed reactor were removed after 40 days, and the remaining concentration was $<100 \mathrm{mg}-\mathrm{TSS} / \mathrm{L}$ at that time.

The total $\mathrm{N}$ removal efficiency of the hydrolysed ricefed reactor was approximately $20 \%$ lower than that of the ethanol-fed reactor. Two possible reasons are suggested to explain this difference: 1) the low net carbon content of hydrolysed rice due to the initial conversion reactions, and 2) the slow diffusion rate of hydrolysed rice into the pellet core. The diffusion rate is slow because hydrolysed rice is composed of glucose polymer, which is much larger than the molecular structure of ethanol. However, at a low $\mathrm{C} / \mathrm{N}$ ratio, the differences in net carbon and diffusion rate on the total $\mathrm{N}$ removal efficiency could not be seen.

\subsection{High C/N Ratio}

At a high $\mathrm{C} / \mathrm{N}$ ratio, the total $\mathrm{N}$ removal efficiency for all reactors was similar, ranging from $63-66 \%$ (Table 2). However, large quantities of free cells were found in the acetate- and ethanol-fed reactors $(\sim 1000 \mathrm{mg}-\mathrm{TSS} / \mathrm{L}$ in the acetate-fed reactor and $\sim 700 \mathrm{mg}-\mathrm{TSS} / \mathrm{L}$ in the ethanol-fed reactor after 60 days). The explanation for the occurrence of free cells in the ethanol-fed reactor is the same as that previously postulated for the acetate-fed reactor. In the presence of a large number of free cells, the carbon source has no effect on the total $\mathrm{N}$ removal efficiency.

No free cells were found in the reactor when hydrolysed rice was used as the carbon source, indicating that most of the carbon was consumed by denitrifying bacteria. This is confirmed by the step-wise increase in efficiency with increasing $\mathrm{C} / \mathrm{N}$ ratio (Figure 3). The slow increase in competitive bacteria (entrapped in the pellet) in this reactor is one advantage of using hydrolysed rice as the carbon source. However, hydrolysed rice requires the addition of more carbon to achieve nitrogen removal in comparison with acetate or ethanol.

In comparison to the literature cited in Table 1, the nitrogen removal efficiency in the present work was quite low. The primary reason is the inappropriate reactor design and set-up resulting in a high DO concentration in the non-aeration chamber. Although denitrification occurred, it was not effective. Moreover the high DO concentration and frequent organic carbon feed in the non-aeration chamber induced the rapid growth of competitive bacteria, which was not reported in other in- 
vestigations.

\section{Summary}

1) Acetate is the most efficient carbon source for nitrogen removal as indicated by the efficiency at a $\mathrm{C} / \mathrm{N}$ ratio of 1.5 (no free cells were observed). However, at higher ratios free cells (competitive bacteria) appeared in the acetate-fed reactor. Free cells tend to reduce the efficiency of the denitrification process.

2) Hydrolysed rice is a satisfactory alternative carbon source for nitrogen removal. No free cells were found in the rice-fed reactor. However, further study (including the hydrolysis process) will be required to obtain high nitrogen removal efficiency.

\section{Acknowledgements}

The authors are grateful for the financial support of GCOE program (University of Yamanashi, Japan), which has allowed this and other developmental work to be undertaken, and Ms. Yuki Hiraka for her assistance in operating the bioreactors.

\section{References}

[1] Y. Mokhayeri, R. Riffat, I. Takacs, P. Dold, C. Bott, J. Hinojosa, W. Bailey and S. Murthy, "Characterizing Denitrification Kinetics at Cold Temperature Using Various Carbon Sources in Lab-Scale Sequencing Batch Reactors," Water Science and Technology, Vol. 58, No. 1, January 2008, pp. 233-238.

[2] T. Osaka, K. Shirotani, S. Yoshie and S. Tsuneda, "Effects of Carbon Source on Denitrification Efficiency and Microbial Community Structure in a Saline Wastewater Treatment Process," Water Research, Vol. 42, No. 2, June 2008, pp. 3709-3718.

[3] Y. Otani, K. Hasegawa and K. Hanaki, "Comparison of Aerobic Denitrifying Activity among Three Cultural Species with Various Carbon Source," Water Science and Technology, Vol. 50, No. 8, April 2004, pp. 15-22.

[4] M. P. Ginige, J. C. Bowyer, L. Foley, J. Keller and Z. Yuan, "A Comparative Study of Methanol as a Supplementary Carbon Source for Enhancing Denitrification in Primary and Secondary Anoxic Zones," Biodegradation, Vol. 20, No. 2, September 2009, pp. 221-234.

[5] J. C. Akuna, C. Bizeau and R. Moletta, "Nitrate and Nitrite Reductions with Anaerobic Sludge Using Various
Carbon Sources: Glucose, Glycerol, Acetic Acid, Lactic Acid and Methanol," Water Research, Vol. 27, No. 2, April 1993, pp. 1303-1312.

[6] Z. Quan, Y. Jin, C. Yin, J. J. Lee and S. Lee, "Hydrolyzed Molasses as an External Carbon Source in Biological Nitrogen Removal," Bioresource Technology, Vol. 96, No. 15, February 2005, pp. 1690-1695.

[7] Z. Xu, L. Shao, H. Yin, H. Chu and Y. Yao, "Biological Denitrification Using Corncobs as a Carbon Source and Biofilm Carrier," Water Environment Research, Vol. 81, No. 3, March 2009, pp. 242-247.

[8] V. Aravinthan, T. Mino, S. Takizawa, H. Satoh and T. Matsuo, "Sludge Hydrolysate as a Carbon Source for Denitrification," Water Science and Technology, Vol. 43, No. 1, January 2001, pp. 191-199.

[9] H. Constantin and M. Fick, "Influence of C-Sources on the Denitrification Rate of a High-Nitrate Concentrated Industrial Wastewater," Water Research, Vol. 31, No. 3, February 1997, pp. 583-589.

[10] A. Mohseni-Bandpi and D. J. Elliott, "Groundwater Denitrification with Alternative Carbon Sources," Water Science and Technology, Vol. 38, No. 6, March 1998, pp. 237-243.

[11] K. Heylen, B. Vanparys, L. Wittebolle, W. Verstraete, N. Boon and P. de Vos, "Cultivation of Denitrifying Bacteria: Optimization of Isolation Conditions and Diversity Study," Applied and Environmental Microbiology, Vol. 72, No. 4, April 2006, pp. 2637-2643.

[12] American Public Health Association, "Standard Methods for the Examination of Water and Wastewater," 19th Edition, APHA, AWWA, WEF, Am Public Health Assoc Byrd Progress, Springfield, New York, 1995.

[13] B. Jun, K. Miyanaga, Y. Tanji and H. Unno. "Removal of Nitrogenous and Carbonaceous Substrates by a Porous Carrier - Membrance Hybrid Process for Wastewater Treatment," Biochemical Engineering Journal, August 2003, Vol. 14, No. 1, pp. 37-44.

[14] J. C. Akunna, C. Bizeau and R. Moletta, "Denitrification in Anaerobic Digesters: Possibilities and Influence of Wastewater COD/N-NO ${ }_{x}$ Ratio," Environmental Technology, Vol. 13, No. 1, April 1992, pp. 825-836.

[15] D. R. Lide, "CRC Handbook of Chemistry and Physics," 81st Edition, CRC Press, Boca Raton, 2000.

[16] K. A. Third, N. Burnett and R. Cord-Ruwisch, "Simultaneous Nitrification and Denitrification Using Stored Substrate (PHB) as the Electron Donor in an SBR," Biotechnology and Bioengineering, Vol. 83, No. 6, June 2003, pp. 706-720. 